\title{
Nitroglycerine as a Hypotensive Agent in Ear, Nose, and Throat Surgery
}

Said A. Latief

\begin{abstract}
Abstrak
Larutan $0.01 \%$ Nitrogliserin telah digunakan untuk menimbulkan hipotensi terkendali pada 30 penderita bedah THT (Telinga, Hidung, Tenggorok). Nitrogliserin ini dapat bekerja efektif sebagai obat hipotensif yang aman selama anestesia umum dengan menghasilkan lapangan operasi yang kering dan mengurangi jumlah kehilangan darah akibat pembedahan pada semua kasus.
\end{abstract}

\begin{abstract}
A $0.01 \%$ Nitroglycerine solution was used to induce controlled hypotension in 30 consecutive ENT (Ear, Nose, Throat) surgery. It was found to be effective as a safe hypotensive drug during general anesthesia. It readily produced a dry operative field, decreased operative blood loss in all cases.
\end{abstract}

Keywords: Anesthetic technique, induced hypotension, nitroglycerine. surgery: ear-nose throat.

\section{INTRODUCTION}

Deliberate hypotension as an adjunct to general anesthesia provides a relatively bloodless surgical field, decreases operative blood loss and deminishes the need for and risks of blood transfusion. ${ }^{1}$

It has also been suggested that a reduction of blood pressure by $20-40 \mathrm{mmHg}$ is sufficient to reduce bleeding. ${ }^{2}$ The drugs currently used for this purpose include halothane, enflurane, isoflurane, lytic cocktails,neurolept analgetics, ganglionic-blocking-agents, beta blockers or vasodilators such as sodium nitroprusside or nitroglycerine. ${ }^{1,2,3}$

Halothane alone can be used to produce hypotension, but at the risk of direct myocardial depression. ${ }^{2}$ Hypotension with a ganglionic blocking agent is associated with undesirable side effects related to blockade of parasympathetic ganglia and development of tachyphylaxis. ${ }^{4}$ Sodium nitroprusside is not free of adverse effects such as: tachyphylaxis, cyanide toxicity and death, which have all been reported. ${ }^{5}$ This paper reports a technique for the induction of controlled hypotension in ENT surgery using different doses of nitroglycerine (glyceryl trinitrate, nitrostat, nitro- cine)and the time of onset of hypotension subsequent to the use of different concentrations of the drug.

\section{MATERIALS AND METHODS}

Subjects of the study were 30 adult patients scheduled for ENT surgery with general anesthesia and induced arterial hypotension in Dr. Cipto Mangunkusumo Hospital Jakarta. They were randomly allocated into two groups according to the initial dose of the hypotensive agent used.

Group 1 consisted of 15 patients, 9 male and 6 female,aged $30.53 \pm 12.03$ years and weighing 54.47 $\pm 8.33 \mathrm{kgs}$, receiving an initial dose of $1 \mu \mathrm{g} / \mathrm{kg} /$ minute of $0.01 \%$ nitroglycerine.

Group 2 consisted of 15 patients, 8 male and 7 female aged $28.33 \pm 13.29$ years and weighing 51.67 $\pm 8.17 \mathrm{kgs}$, receiving an initial dose of $5 \mu \mathrm{g} / \mathrm{kg} /$ minute of the same drug.The groups were comparable in age, sex distribution and weight $(p>0.05)$ as seen in table 1. All subjects were in good condition as judged by physical or laboratory examination and none had a history of clinical evidence of cardiovascular, pulmonary, liver or metabolic disease.

\footnotetext{
* Department of Anesthesiology, Faculty of Medicine, University of Indonesia, Jakarta, Indonesia
} 
Table 1. Mean age,mean weight and sex distribution.

\begin{tabular}{lcc}
\hline Sex distribution & Group 1 & Group 2 \\
\hline Male & 9 & 8 \\
Female & 6 & 7 \\
\hline Total & 15 & 15 \\
\hline Mean age (years) & $30.53 \pm 12.03$ & $28.33 \pm 13.29$ \\
\hline Mean weight (kgs) & $54.47 \pm 08.33$ & $51.67 \pm 08.17$ \\
\hline
\end{tabular}

A sterile solution of $0.1 \%$ nitroglycerine (ampoule containing $10 \mathrm{mg}$ nitroglycerine in $10 \mathrm{ml}$ isotonic sterile solution, Schwarz Pharma, PT Pharos Indonesia) was diluted further to a $0.01 \%$ solution with $5 \%$ Dextrose in water (Otsuka).

Prior to premedication of anesthesia a 16 or $18 \mathrm{G}$ teflon peripheral venous catheter was inserted percutaneously into the dorsum vein of the hand for fluid and drug administration. Lactated ringer's solution was infused at a rate of $5 \mathrm{ml} / \mathrm{kg} /$ hour. A standard technique of anesthesia was employed for both groups of patients. Premedication consisted of $1 \mathrm{mg} / \mathrm{kg}$ pethidine $\mathrm{HCl}$ (Kimia Farma) and $0.1 \mathrm{mg} / \mathrm{kg}$ dehydrobenzperidol (Janssens) given intramuscularly 30-60 minutes before the induction of anesthesia. Vecuronium (Norcuron, Organon) $0.1 \mathrm{mg} / \mathrm{kg}$ was used for relaxation to facilitate endotracheal intubation with cuffed tube and maintenance of anesthesia followed by $3-5 / \mathrm{kg}$ of sodium thiopental (Pentothal Abbott) for induction of anesthesia.

Anesthesia was maintained with $0.5 \%$ to 1 vol \% halothane inspired concentration in nitrous oxide and $\mathrm{O}_{2} 3: 2$ liter/minute using a semiclosed system with carbon dioxide absorber. In each patient, the inspired halothane concentration was maintained constant before and during administration of the hypotensive drug. Ventilation was controlled to maintained normoventilation by using a Pneumador ventilator machine as determined by repeated measurements of arterial blood gases. Hypotension was induced before incision of the skin when anesthesia was adequate. All patients were in 15 degree head-up tilt position and remained in that position throughout the operation.

Infusion of $0.01 \%$ nitroglycerine was administered through a $20 \mathrm{G}$ venous catheter in the saphenous vein. To ensure a constant rate of infusion the author used a B Braun syringe pump. Pediatric microdrop ( $1 \mathrm{ml}=60$ drops) or a standard drop ( $1 \mathrm{ml}=$ 20 drops) can also be used. An initial dose of 1 $\mu \mathrm{g} / \mathrm{kg} / \mathrm{min}$ nitroglycerine for group 1 and $5 \mu \mathrm{g} / \mathrm{kg} / \mathrm{min}$ for group 2 was begun and followed by the addition of $1 \mu \mathrm{g} / \mathrm{kg} / \mathrm{min}$ every 2 minute for both groups. The total dose was not more than $7 \mu \mathrm{g} / \mathrm{kg} / \mathrm{min}$. The systolic blood pressure was adjusted to decrease and maintained at about $70 \mathrm{~mm} \mathrm{Hg}$. This level of blood pressure was compatible with a dry operative field as determined by the surgeons who did not know which hypotensive drug was being administered.To secure hemostasis, drug infusion was discontinued and arterial pressure allowed to return to the prehypotension value before wound closure.

Table 2. The operation performed on the subjects of the study.

\begin{tabular}{lc}
\hline Sinus surgery (Caldwell-Luc etc) & 12 patients \\
Nasopharyngeal surgery (angiofibrome etc) & 8 patients \\
Tympanoplasty & 5 patients \\
Mastoidectomy & 4 patients \\
Laryngectomy & 1 patient \\
\hline Total & 30 patients \\
\hline
\end{tabular}

Monitoring was done continuously before, during and after induced hypotension by taking the following measures:

1. Arterial blood pressure and pulse rate were recorded at 2.5 min intervals using a Dynamap sphygnomanometer inflated automatically.

2. The heart rate and ECG were recorded continously using cardiopac 3M12 San-Ei.

3. Blood gas analysis was monitored at 15 min intervals to maintained ventilation normocapnia and good oxygenation.

4. Urine production was measured continuously using urine bag.

5. Bleeding was classified as slight, moderate or severe.

\section{RESULTS}

Before induced hypotension,the blood pressure (systolic, diastolic, mean arterial pressure) and the heart rate of the two groups were compared and no significant differences were found $(p>0.05)$ as seen in Table 3. 
Table 3. Blood pressure and heart rate values before,during and after induced hypotension wit nitroglycerine.

\begin{tabular}{lrrrrrrrr}
\hline & \multicolumn{2}{c}{$\begin{array}{c}\text { Before } \\
\text { Hypotension }\end{array}$} & \multicolumn{2}{c}{$\begin{array}{c}15 \text { min } \\
\text { Hypotension }\end{array}$} & \multicolumn{2}{c}{$\begin{array}{c}30 \text { min } \\
\text { Hypotension }\end{array}$} & \multicolumn{1}{c}{$\begin{array}{c}15 \text { min } \\
\text { Post hypotension }\end{array}$} \\
\cline { 2 - 9 } & Grp 1 & Grp 2 & Grp 1 & Grp 2 & Grp 1 & Grp 2 & Grp 1 & Grp 2 \\
\hline Systolic & 120.67 & 118.33 & 84.55 & 79.20 & 76.64 & 75.15 & 106.21 & 104.60 \\
SD & 7.04 & 6.46 & 1.41 & 1.62 & 2.83 & 2.26 & 5.13 & 2.80 \\
Diastolic & 76.33 & 77.30 & 52.64 & 46.70 & 44.15 & 45.28 & 60.69 & 60.40 \\
SD & 5.81 & 4.58 & 4.06 & 2.24 & 3.16 & 3.11 & 4.14 & 3.64 \\
Mean A P & 90.80 & 88.47 & 62.72 & 57.95 & 55.40 & 55.09 & 73.86 & 73.65 \\
SD & 5.31 & 4.37 & 2.04 & 4.87 & 2.60 & 1.40 & 3.48 & 2.60 \\
Heart rate & 87.80 & 87.67 & 95.49 & 99.43 & 102.67 & 106.33 & 91.45 & 96.17 \\
SD & 6.87 & 9.63 & 5.85 & 8.89 & 6.17 & 9.63 & 8.31 & 14.70 \\
\hline
\end{tabular}

Fifteen and thirty minutes following nitroglycerine administration, a significant increase in heart rate occured in the two groups. Between these two groups, the difference was not significant $(p>0.05)$ as seen in Table 3.

Fifteen and thirty minutes after following nitroglycerine administration, arterial systolic, diastolic and mean arterial pressure decreased significantly in both groups if compared with data before hypotension was induced.

The ECG, the arterial blood gases and the urine production of all patients before and after hypotension were within normal limits. After the initial injection of nitroglycerine, the arterial systolic blood pressure decreased quickly in both groups, reaching $70-90 \mathrm{mmHg}$ in a few minutes. The onset time of hypotension was quicker in group $2(5 \mu \mathrm{g} / \mathrm{kg} / \mathrm{min})$ compared to group 1 $(1 \mu \mathrm{g} / \mathrm{kg} / \mathrm{min})$ as seen in table 4 . The data was compared and a significant difference was found $(p<0.01)$.

Table 4. The onset time (minutes) of systolic hypotension (70$90 \mathrm{mmHg}$ ) in Group 1 and 2.

\begin{tabular}{lccc}
\hline & Time (min) & SD & $\mathrm{N}$ \\
\hline Group 1 & 9.53 & 1.19 & 15 \\
Group 2 & 5.40 & 1.12 & 15 \\
\hline
\end{tabular}

The assessment of the operative field throughout the procedure was made by the surgeons with the classification : excellent, good or unsatisfactory as seen in Table 5.
Table 5. The classification of the operative fields.

\begin{tabular}{lccc}
\hline & Group 1 & Group 2 & N \\
\hline Excellent & 1 & 3 & 4 \\
Good & 14 & 12 & 26 \\
Unsatisfactory & - & - & - \\
\hline Total & 15 & 15 & 30 \\
\hline
\end{tabular}

No difficulties were found in restoring arterial blood pressure to pre-hypotension level in all patients and hypotension could be induced in all patients. The mean duration of surgery and infusion, the total nitroglycerine used and the mean doses are shown in Table 5.

Table 5. Duration of surgery (min), duration of infusion (min) and mean dose of nitroglycerine (mgs).

\begin{tabular}{lcccc}
\hline & \multicolumn{2}{c}{ Group 1 } & \multicolumn{2}{c}{ Group 2 } \\
\cline { 2 - 5 } & Mean & SD & Mean & SD \\
\hline Duration of surgery & 120.67 & 36.72 & 128.33 & 46.07 \\
Duration of infusion & 93.33 & 32.00 & 96.00 & 36.21 \\
Total nitro used & 22.03 & 9.01 & 21.77 & 7.78 \\
Mean dose $(\mu \mathrm{g} / \mathrm{kg} / \mathrm{min})$ & 4.40 & 0.48 & 4.43 & 0.71 \\
\hline
\end{tabular}




\section{DISCUSSION}

This study demonstrates that nitroglycerine can be effective as a hypotensive drug during general anesthesia. Decrease of the arterial systolic blood pressure to between $70-80 \mathrm{mmHg}$, gave satisfactory hemostasis around the surgical field in all cases and was acceptable to the surgeons. To produce a blood free surgical field for surgery, the arterial blood pressure can be reduced to less than $50 \mathrm{mmHg}$, but this may induced risks, such as renal artery shut-down. ${ }^{3,6}$ Nitroglycerine induced hypotension was directly related to the rate of infusion and the response of the patients was rapid. Discontinuation of the drug infusion returns the arterial blood pressure to the pre treatment level. ${ }^{1}$ Nitroglycerine induced hypotension is related primary to a direct effect of the drug on the vascular smooth muscle, both resistance and capacitance vessels are dilated but the effect on the latter is predominant. ${ }^{7}$

There are many variations of the starting dose of nitroglycerine. A starting dose of $10-20 \mu \mathrm{g} / \mathrm{min}^{1,2,8}$ is recommended for the control of hypertension or to produce hypotension during surgery. The recommended dosage range is $10-400 \mu \mathrm{g} / \mathrm{min}^{2,8}$ There is no fixed optimum dose of nitroglycerine, due to different individual responsiveness. Each patient must be titrated to the desired level of hemodynamic. At low doses of nitroglycerine (10-25 $\mu \mathrm{g} / \mathrm{min})$, hypotensive effects are achieved very slowly and this is not acceptable for most of the surgeons. So, the author wants to find a correct starting dose to be used in correlation with surgical intervention. The safety and efficacy of nitroglycerine has not yet been established in children, during pregnancy and lactation. Therefore it should not be used in these cases unless considered essential. ${ }^{8}$

Atropine was not used as a premedication and avoided because the associated tachycardia can cause a resistance to profound hypotension. ${ }^{3}$ Eltringham ${ }^{9}$ maintained the heart rate below 70 beats $/ \mathrm{min}$ by the addition of intravenous propranolol in $1 \mathrm{mg}$ increments as required. ${ }^{10}$ Moderately deep anesthesia is necessary to prevent coughing and straining with consequent bleeding as a result of an increase in venous pressure. ${ }^{2,3}$ The halothane $0.5-1.0 \mathrm{vol} \%$ plus nitrousoxide-oxygen and pethidine was found to be satisfactory and gave an adequate depth of anesthesia.

\section{CONCLUSION}

The result of this study showed that nitroglycerine is effective as a hypotensive drug, easy to administer and has a rapid onset, especially with higher initial doses, with absence of side effects.

\section{REFERENCES}

1. Fahmy NR.Nitroglycerine as a hypotensive drug during general anesthesia. Anesthesiology 1978; 49: 17-20.

2. Atkinson RS, Rushman GB, Alfred Lee J. Production of ischemia during operation. In:A synopsis of Anesthesia. 1st PG Asian Ed 1988 ; 299-310.

3. Kerr AR. Anesthesia with profound hypotension for middle ear surgery Brit J Anesth $1977 ; 49:$ 447-52.

4. Fahmy NR, Laver MB. Hemodynamic response to ganglionic blockade with pentolinium during N2O-Halothane anesthesia in man.Anesthesiology 1976; $44: 6-15$.

5. Tinker JH, Michenfehler JD. Sodium nitroprusside : Pharmacology, toxicology and therapeutics. Anesthesiology 1976 ; 45 : 340 - 54.

6. Best HC, Taylor NB. Physiology of medical practice. Baltimore. Williams and Wilkins. $1973 ; 3$.

7. Mason DT, Zelis R, Amsterdam ES. Action of the nitrate on the peripheral circulation and myocardial oxygen consumption: Significance in the relief of angina pectoris. Chest $1971 ; 59: 296-305$.

8. Schwarz Pharma. PT Pharos Indonesia. Personal communication.

9. Flaherty JT, Reid PR, Kelly DT. Intravenous nitroglycerine in acute myocardial infarction. Circulation $1975 ; 50: 132$ $-9$.

10. Eltringham RJ, Little John PA, Young PN and Robinson JM. Glyceryl trinitrate as a hypotentive agent in middle ear surgery. J Int Med Research 1987 ; 15 : 251-3. 